\title{
Primary Biliary Cirrhosis with a normal Alkaline Phosphatase: a
} \section{case report} Joshua M Brostoff*1, Sukaina Rashid ${ }^{2}$ and Daniel McCrea²

\author{
Address: ${ }^{134}$ Fitzjohns Avenue, London, NW3 5NB, UK and ${ }^{2}$ Central Middlesex Hospital, London, NW10 7NS, UK \\ Email: Joshua M Brostoff* - joshbrostoff@doctors.org.uk; Sukaina Rashid - sukaina.rashid1@gmail.com; \\ Daniel McCrea - daniel.mccrea@nwlh.nhs.uk \\ * Corresponding author
}

Published: I4 July 2008

Cases Journal 2008, I:33 doi:10.1 I86/I757-1626-1-33

This article is available from: http://www.casesjournal.com/content/l/I/33

(C) 2008 Brostoff et al; licensee BioMed Central Ltd.

This is an Open Access article distributed under the terms of the Creative Commons Attribution License (http://creativecommons.org/licenses/by/2.0), which permits unrestricted use, distribution, and reproduction in any medium, provided the original work is properly cited.

Received: 22 June 2008

Accepted: 14 July 2008

\begin{abstract}
A 78 year-old lady presented with abdominal swelling and fatigue. She was anaemic with mild hypoalbuminaemia, and had a normal alkaline phosphatase. Computed tomography showed hepatosplenomegaly and mild ascites. Anti mitochondrial antibodies were strongly positive, as were anti nuclear antibodies, and the gamma glutamyl-transferase was shown to be elevated. A diagnosis of primary biliary cirrhosis was made. A brief discussion of treatment of primary biliary cirrhosis follows. The case is notable for the fact that primary biliary cirrhosis can manifest clinically without an elevation in alkaline phosphatase - normally the hallmark of the disease.
\end{abstract}

\section{Case presentation}

A 78 year-old lady of West Indian origin presented with a 4 week history of diarrhoea and progressive abdominal swelling, as well as shortness of breath and poor mobility over the same period. She denied any other symptoms, foreign travel, infectious contacts, or family history of note. Her past medical history included hypertension, glaucoma, and well-controlled type two diabetes mellitus. Medications were bendrofluazide, gliclazide and metformin, and she had no allergies. She was unmarried and had no children. The patient was a non-smoker, and drank one small glass of whisky per day.

Physical examination revealed a grossly distended, nontender abdomen with shifting dullness. There was no palpable organomegaly, and bowel sounds were normal. A digital rectal exam showed watery mucus but no masses. There was pedal oedema bilaterally, and fine inspiratory crepitations audible at both lung bases.
Initial laboratory investigations revealed a haemoglobin (Hb) of $9.0 \mathrm{~g} / \mathrm{dl}$ (NR 11.5-15.5) with a mean corpuscular volume (MCV) of $86 \mathrm{fl}$ (NR 78-100) but otherwise normal haematological indices. The biochemical and clotting profiles were normal apart from an albumin of $28 \mathrm{~g} / \mathrm{L}$ (NR 35-50), and thyroid function tests were normal. CT scanning revealed hepatosplenomegaly and moderate ascites but no pleural effusions, and echocardiography showed moderate diastolic dysfunction with structurally normal valves.

Further blood results returned showing a gammaglutamyl transferase (GGT) of 140 IU/L (NR 9-36), and a polyclonal increase in gammaglobulins with normal IgM fraction. Autoimmune profile showed strongly positive anti-mitochondrial antibodies, and anti-nuclear antibodies staining in a centromere pattern. A diagnosis of PBC was made and the patient was started on ursodeoxycholic acid. In view of the patient's age and frailty a liver biopsy was not undertaken. 


\section{Discussion}

Primary biliary cirrhosis (PBC) is a presumed autoimmune disease of the liver, which is most commonly diagnosed in women between the ages of 30 and 65. In the modern era most cases are diagnosed when asymptomatic, usually presenting with abnormal LFTs. Symptoms can include fatigue, pruritus, rheumatic symptoms, skin hyperpigmentation, and right upper quadrant pain [1].

The antimitochondrial antibody is the serological hallmark of disease and is present in the serum of nearly all affected patients [2]; likewise the serum alkaline phosphatase (ALP) level is almost always raised, often to striking levels [3].

Treatment is aimed at alleviating the symptoms and complications of the disease, and attempting to suppress the continuing destruction of small bile ducts. Ursodeoxycholic acid (UDCA) may work by suppressin release of endogenous bile acids which are toxic to hepatocytes, and it also inhibits eosinophil activation, which may have a pathogenic role in PBC. UDCA at approximately 13 to 15 $\mathrm{mg} / \mathrm{kg}$ per day has been studied extensively in individual trials and has been the subject of at least 3 meta-analyses [4]. Results of these are conflicting, but considering the results of the individual trials, the few effective available alternative treatments for patients with $\mathrm{PBC}$, and the excellent tolerability of UDCA, it is still widely considered first line therapy.

This case is unusual for several reasons. The patient was diagnosed at an older age than is usual with PBC. She had unusual presenting symptoms, with ascites as her chief complaint. Most important, this case highlights that PBC can exist with an entirely normal ALP, and here the diagnosis hinged on a high index of suspicion and an elevated GGT.

At our hospital GGT is not included in routine liver function tests, and needs to be specifically requested. It was only after the elevated GGT was noted despite the normal ALP that we began to strongly suspect cholestasis and therefore PBC. Hence we suggest that GGT is always included in routine liver function tests.

\section{Abbreviations}

ALP: Alkaline Phosphatase. CT: Computed Tomography. GGT: Gamma Glutamyl-Transferase. Hb: Haemoglobin. LFT: Liver Function Tests. MCV: Mean Corpuscular Volume. NR: Normal Range. PBC: Primary Biliary Cirrhosis. UDCA: Urso Deoxycholic Acid.

\section{Competing interests}

The authors declare that they have no competing interests.

\section{Authors' contributions}

Case report written by SR and JMB. Discussion written by JMB and DM.

\section{Consent}

The patient has died since the original presentation, and leaves behind no next-of-kin.

\section{References}

I. Prince MI, Chetwynd A, Craig WL, Metcalf JV, James OF: Asymptomatic primary biliary cirrhosis: clinical features, prognosis, and symptom progression in a large population based cohort. Gut 2004, 53(6):865-70.

2. Water J Van de, Cooper A, Surh CD, Coppel R, Danner D, Ansari A, Dickson R, Gershwin ME: Detection of autoantibodies to recombinant mitochondrial proteins in patients with primary biliary cirrhosis. N Engl J Med 1989, 320(21): I377-80.

3. Christensen E, Crowe J, Doniach D, Popper H, Ranek L, Rodes J, Tygstrup N, Williams R: Clinical pattern and course of disease in primary biliary cirrhosis based on an analysis of 236 patients. Gastroenterology 1980, 78(2):236-46.

4. Silveira MG, Lindor KD: Treatment of primary biliary cirrhosis: therapy with choleretic and immunosuppressive agents. Clin Liver Dis 2008, I 2(2):425-43.
Publish with Bio Med Central and every scientist can read your work free of charge

"BioMed Central will be the most significant development for disseminating the results of biomedical research in our lifetime." Sir Paul Nurse, Cancer Research UK

Your research papers will be:

- available free of charge to the entire biomedical community

- peer reviewed and published immediately upon acceptance

- cited in PubMed and archived on PubMed Central

- yours - you keep the copyright

Submit your manuscript here:

http://www.biomedcentral.com/info/publishing_adv.asp
BioMedcentral 